\title{
Pollination ecology and breeding system of two Calceolaria species in Chile
}

\author{
Maureen Murúa ${ }^{1,2^{*}}$, Jannina Cisterna ${ }^{1}$ and Benito Rosende ${ }^{3}$
}

\section{Findings}

Many angiosperms are exclusively dependent on pollinators for its reproduction (Matallana et al. 2010; Arroyo et al. 2006). However, pollinators sometimes could be erratic and variable in relation to the ecological context (e.g., plant community composition), especially in alpine zones where it is known that pollinators decline in abundance with the increment in altitude (Arroyo and Squeo 1990; Totland 1994). The latest could be critical in specialized pollination system and more over when specialized flowering plants inhabit in sympatry, potentially sharing the specialized floral visitors. In this context, it is expected that plant species develop reproductive strategies to ensure reproduction and/or exhibit some differences in their pollination ecology.

Calceolaria filicaulis Graham (Calceolariaceae) and Calceolaria arachnoidea Clos (Calceolariaceae) are perennial herbs that grow in streams and rivers in the high Andean region of Chile (Ehrhart 2000). Except for some specific localities in central Chile, the two species have ranges that do not overlap (Ehrhart 2000). The flowers are zygomorphic and composed of a small superior lobe that covers the reproductive structures and an inflated lower lobe that contains the oil-secreting gland (Sérsic 2004). Species differ in many morphological traits, especially those related to corolla characteristics (Figure 1). On the one hand, C. filicaulis has a yellow corolla and the oil gland is situated close to its aperture, enabling a better access to pollinators. On the other hand, $C$. arachnoidea has a purple corolla and the oil gland is hidden in the inferior lobe. Recent studies indicate that the pollination service of this genus is done by a particular group of bees of the genera Centris and Chalepogenus that possess specialized structures for oil collection (Figure 1; Sérsic 2004).

This study was conducted during the summer season of 2012 at the National Reserve Altos de Lircay (35 36' S,

\footnotetext{
* Correspondence: mmurua@u.uchile.cl

'Departamento de Ciencias Ecológicas, Facultad de Ciencias, Universidad de Chile, Las Palmeras 3425, Casilla, Santiago 653, Chile

2Jardín Botánico Nacional, Calle Camino el Olivar, Viña del Mar 305, Chile Full list of author information is available at the end of the article
}

$\left.71^{\circ} 00^{\prime} \mathrm{W}\right)$ in the Región del Maule, Chile. The sample site is located in the Reserve at 2,200 m a.s.l. and has a Mediterranean-type climate, with most rainfall concentrated in the winter season (di Castri and Hajek 1976). In the study site, $C$. filicaulis and $C$. arachnoidea inhabit in sympatry and are distributed in monospecific patches, surrounded by a vegetation matrix that includes Mimulus luteus Linnaeus (Schrophulareaceae), Mimulus cupreus Dombrain (Schrophulareaceae), Hypochoeris acaulis Britton (Asteraceae), Pozoa coriacea Lagasca \& Segura (Apiaceae), and Azorella incisa Weddell (Apiaceae).

To determine the breeding system of Calceolaria species, a pollination-controlled experiment was conducted in 120 buds per species. Buds were bagged with a mesh, and each of the following treatments were randomly assigned: (1) control (C), intact flowers exposed to natural pollination; (2) hand cross-pollination (HC), emasculated flowers pollinated with pollen from another plant situated at least $1 \mathrm{~m}$ apart; (3) automatic pollination (AP), bagged buds without manipulation; and (4) hand self-pollination (HS), emasculated flowers pollinated by its own pollen. Pollination success was estimated as seed set per plant, and self-incompatibility (ISI) and autogamy (IAS) indexes (Arroyo and Uslar 1993) were estimated as

$$
\text { ISI }=\frac{n^{\circ} \overline{\mathrm{HS}}}{n^{\circ} \overline{\mathrm{HC}}} \quad \text { IAS }=\frac{n^{\circ} \overline{\mathrm{HS}}}{n^{\circ} \overline{\mathrm{AP}}}
$$

where, $\overline{\mathrm{HS}}, \overline{\mathrm{HC}}$, and $\overline{\mathrm{AP}}$ represents the average number of seed per fruit on each treatment. The significance of treatment effects was evaluated on log-transformed data by two-way ANOVA. Statistical differences among treatments were evaluated in a post hoc Tukey test in R package version 2.15 ( $\mathrm{R}$ development Core Team, 2011). To characterize pollination ecology, all flower visitors of both Calceolaria species were recorded. Focal observations of 15 min per plant were realized during six consecutive sunny days between 0900 and 1800 hours ( $50 \mathrm{~h}$ of observation per specie). All floral visitors contacting the 


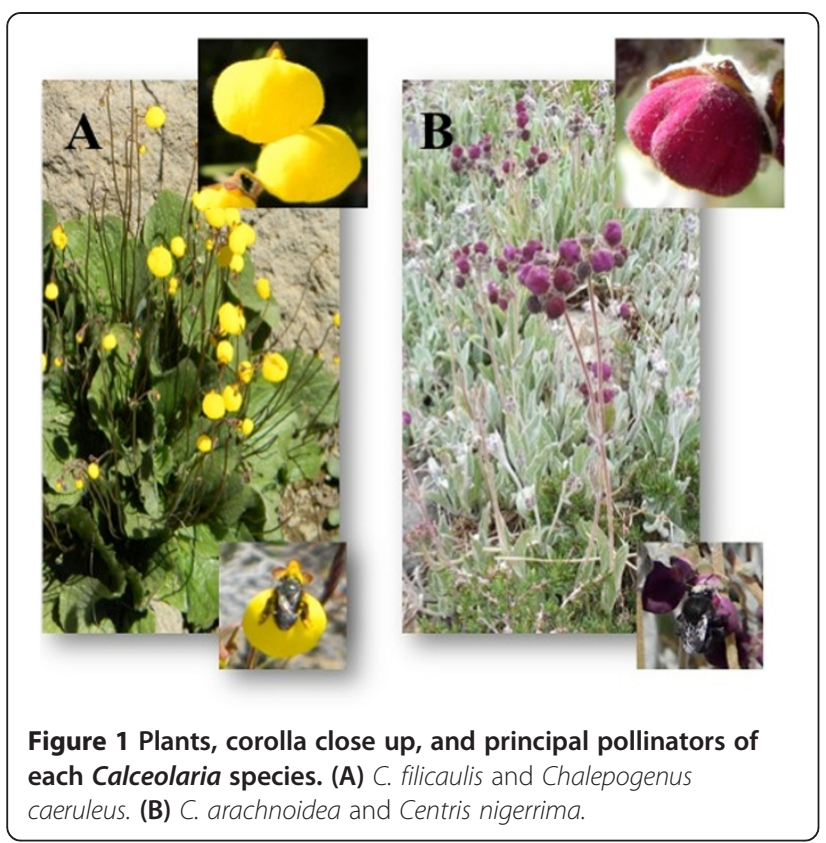

reproductive structures of the flowers were captured and taken to the laboratory for taxonomic identification.

The results of the pollination experiment showed that no seeds were produced in the absence of pollinators. The comparison between treatments revealed that there was a significant effect of treatments on seed production for both Calceolaria species (C. filicaulis: $F_{2,66}=4.85$, $P=0.01 ; \quad C$. arachnoidea: $F_{2,82}=28.34, \quad P<0.0001$ ). Tukey's post hoc comparison showed that for both species, HS produced less seed compared to HC (C. filicaulis: $P=0.01$; C. arachnoidea: $P<0.0001)$. However, the comparison between natural and supplementary pollination treatments showed different results. In $C$. filicaulis, neither HS $(P=0.15)$ nor HC $(P=0.27)$ showed significant differences with control conditions, while in $C$. arachnoidea, natural pollination produced more seeds per fruit than HS and $\mathrm{HC}$ treatments $(P<0.0001)$. Finally, the controlled hand pollination indicated that $C$. filicaulis is allogamous $(\mathrm{IAS}=0)$ and self-incompatible (ISI $=0.14$ ), whereas $C$. arachnoidea is partially autogamous (IAS $=0.21$ ) and selfcompatible (ISI $=0.22$ ). Pollinator assemblages of both Calceolaria species were totally composed of hymenopterans. However, Calceolaria species differ in terms of the number of species responsible for pollination (Table 1). For $C$. arachnoidea, the pollinator assemblage was composed of four species, while for $C$. filicaulis, just two species were responsible for all pollination service. The overall visit rate (mean $\pm \mathrm{SE}$ ) was lower for $C$. arachnoidea $(0.09 \pm 0.07)$ than for $C$. filicaulis $(0.17 \pm 0.12)$. Nonetheless, the identity of the principal pollinator was different in both species. For C. arachnoidea, the principal pollinator was Centris nigerrima Spinola (Apidae) (86\% of total
Table 1 Floral visitors of each studied Calceolaria species

\begin{tabular}{llll}
\hline $\begin{array}{l}\text { Plant } \\
\text { species }\end{array}$ & Pollinators & $\begin{array}{l}\text { Visitation rate } \\
\text { (Visits flower } \mathbf{~ h}^{-\mathbf{1}} \text { ) }\end{array}$ & $\begin{array}{l}\text { Proportion } \\
\text { of visits }\end{array}$ \\
\hline C. filicaulis & $\begin{array}{l}\text { Chalepogenus } \\
\text { caeruleus }\end{array}$ & $0.29 \pm 0.07$ & 0.831 \\
& $\begin{array}{l}\text { Bombus terrestris } \\
\text { C. arachnoidea }\end{array}$ & $0.06 \pm 0.03$ & 0.169 \\
& Centris nigerrima & $0.30 \pm 0.04$ & 0.872 \\
& $\begin{array}{l}\text { Bombus terrestris } \\
\text { Chalepogenus sp. 1 }\end{array}$ & $0.04 \pm 0.20$ & 0.121 \\
& Megachile semirufa & $0.001 \pm 0.002$ & 0.006 \\
\hline
\end{tabular}

Pollinator identity, mean visitation rate ( \pm S.E.), and proportion of visits per insect species.

visits) and for C. filicaulis was Chalepogenus caeruleus Friese (Apidae), representing $82 \%$ of total visits.

In general, our results showed that Calceolaria species are highly dependent on pollinator for reproduction; however, they are able to self-fertilize and showed differences in their reproductive strategies. C. filicaulis is allogamous and self-incompatible, whereas $C$. arachnoidea is partially autogamous and present an incomplete selfcompatibility. The latest seems to be frequent in flowering plants, in particular in specialized pollination systems (Perez et al. 2009), where the evolution of mixed mating strategies has evolved as stable strategy to deal with variable pollinator environments (see review in Goodwillie et al. 2005). In addition, both Calceolaria species were mainly visited by oil-collecting bees, but they differ in their principal pollinator. Globally, this finding suggest that Calceolaria and their oil-collecting bees could represent a highly specialized system, where plant species develop different reproductive strategies possibly in response to their ecological context. The latest could be explained by the frequency, consistency, and efficiency of their pollinators, which are known to decrease with the increase of elevation (Arroyo et al. 1985, 2006). In fact, in the study site, oil-collecting bees are present in low abundance, and they visit different plant species searching for pollen (MM, personal observation); it is known that this can interfere in plant fecundation through pollen interference and/or competition (Kunin 1997).

Despite that Calceolaria species are one of the most diverse genus in Chile (Fuentes et al. 1995), their biology, systematics, and evolution have been recently the subject of detailed research (Molau 1988; Sérsic 2004; Cosacov et al. 2009). Consequently, although this work represents a preliminary view of the breeding system and pollination ecology of Chilean Calceolaria species, this can be a starting point in the study of ecology and even evolution (e.g., reproductive barriers to speciation) of the genus. In this context, more studies are needed to determine proximal and ultimate mechanisms that are determining this finding in one of the most specialized plant-pollinator systems in Chile. 


\section{Competing interest}

All the authors declare that they have no competing interests.

\section{Authors' contributions}

MM conceived this study and participated on the field and laboratory work, as well in the development of the manuscript. JC and BR participated in the field and laboratory work and drafted the manuscript. All authors read and approved the final manuscript.

\section{Acknowledgements}

We thank Catalina González Brown for commenting the manuscript and CONAF for the sampling permission. This research was funded by the grant Beca de Apoyo a la Realización de la Tesis Doctoral (Folio 24110094, CONICYT) to MM.

\section{Author details}

'Departamento de Ciencias Ecológicas, Facultad de Ciencias, Universidad de Chile, Las Palmeras 3425, Casilla, Santiago 653, Chile. ªrdín Botánico Nacional, Calle Camino el Olivar, Viña del Mar 305, Chile. ${ }^{3}$ Departamento de Ciencias Biológicas, Facultad de Ciencias Biológicas, Universidad Andrés Bello, República, Santiago 237, Chile.

Received: 11 October 2013 Accepted: 24 March 2014

Published: 15 July 2014

\section{References}

Arroyo MTK, Armesto JJ, Primack RB (1985) Community studies in pollination ecology in the high temperate Andes of central Chile II. Effect of temperature on visitation rates and pollination possibilities. Plant Syst Evol 149:187-203

Arroyo MTK, Uslar P (1993) Breeding systems in a temperate Mediterranean-type climate montane sclerophyllous forest in central Chile. Bot J Linn Soc 111:83-102

Arroyo MTK, Squeo FA (1990) Relationships between plant breeding systems and pollination. In: Kawano S (ed) Biological approaches and evolutionary trends in plants. Academic, London

Arroyo MTK, Muñoz MS, Henríquez C, Till-bottraud I, Pérez F (2006) Erratic pollination, high selfing levels and their correlates and consequences in an altitudinally widespread above-tree-line species in the high Andes of Chile. Acta Oecol 30:248-257

Cosacov A, Sérsic A, Sosa V, De-nova A, Nylinder S, Coccuci AA (2009) New insights into the phylogenetic relationships, character evolution, and phylogeographic patterns of Calceolaria (Calceolariaceae). Am J Bot 96(2):2240-2255

di Castri F, Hajek ER (1976) Bioclimatología de Chile. Ediciones de la Universidad Católica de, Chile, Santiago

Ehrhart C (2000) Die Gattung Calceolaria (Scrophulariaceae) in Chile. Bibl Bot $153: 1-283$

Fuentes ER, Montenegro G, Rundel PW, Arroyo MTK, Ginacchio R, Jaksic FM (1995) Functional approaches to biodiversity in the Mediterranean-type ecosystems of central Chile. In: Davis GW, Richardson DM (eds) Mediterranean-type ecosystems: the function of biodiversity. Springer-Verlag, New York

Goodwillie C, Kalisz S, Eckert CG (2005) The evolutionary enigma of mixed mating systems in plants: occurrence, theoretical explanations, and empirical evidence. Annu Rev Ecol Evol Syst 36:47-79

Kunin WE (1997) Population size and density effects in pollination: pollinator foraging and plant reproductive success in experimental arrays of Brassica kaber. J Ecol 85:225-234

Matallana G, Godinho MAS, Guilherme FAG, Belisario M, Cose TS, Wendt T (2010) Breeding systems of Bromeliaceae species: evolution of selfing in the context of sympatric occurrence. Plant Syst Evol 289:57-65

Molau U (1988) Scrophulariaceae-part I. Calceolarieae. Flora Neotrop 47:1-326

R Development Core Team (2011) R: a language and environment for statistical computing. R Foundation for Statistical Computing, Vienna, Austria. http://www.R-project.org/
Perez F, Arroyo MTK, Armesto JJ (2009) Evolution of autonomous selfing accompanies increased specialization in the pollination system of Schizanthus (Solanaceae). Am J Bot 96:1168-1176

Sérsic AN (2004) Pollination biology in the genus Calceolaria L. (Calceolariaceae) Stapfia 82:122

Totland $\varnothing ~(1994)$ Influence of climate, time of day and season, and flower density on insect visitation in alpine Norway. Arct Alpine Res 26:66-71

doi:10.1186/0717-6317-87-7

Cite this article as: Murúa et al:: Pollination ecology and breeding system of two Calceolaria species in Chile. Revista Chilena de Historia Natural 2014 87:7.

\section{Submit your manuscript to a SpringerOpen ${ }^{\mathcal{D}}$ journal and benefit from:}

- Convenient online submission

- Rigorous peer review

- Immediate publication on acceptance

- Open access: articles freely available online

- High visibility within the field

- Retaining the copyright to your article

Submit your next manuscript at $>$ springeropen.com 